The University of Maine

\title{
DigitalCommons@UMaine
}

Marine Sciences Faculty Scholarship

School of Marine Sciences

8-1-1998

\section{Small-Scale Features of Marine Sediments and Their Importance to the Study of Deposit-Feeding}

Les Watling

University of Maine - Main, watling@maine.edu

Follow this and additional works at: https://digitalcommons.library.umaine.edu/sms_facpub

\section{Repository Citation}

Watling, Les, "Small-Scale Features of Marine Sediments and Their Importance to the Study of Deposit-Feeding" (1998). Marine Sciences Faculty Scholarship. 123.

https://digitalcommons.library.umaine.edu/sms_facpub/123 


\title{
Small-scale features of marine sediments and their importance to the study of deposit-feeding
}

\author{
Les Watling \\ Darling Marine Center, University of Maine, Walpole, Maine 04573, USA
}

\begin{abstract}
Techniques currently in use by sedimentologists for the study of marine sediment microfabric are of limited use for understanding the relationship between sediment organic matter and mineral grains. In this article it is shown that by combining standard histological protocols for fixation and dehydration with petrological protocols for resin embedding and thin sectioning, very fine details of the sediment structure can be seen. Because of the ubiquitous presence of the organic matrix, organicmineral aggregates are not seen in situ. Other features of the sediment of importance to deposit-feeders, such as the presence of intact chloroplasts, can be observed through the use of epifluorescence illumination, while partially crossed polarizers help to delimit the grain boundaries. It is suggested that if these procedures can be combined with histological staining techniques, it may be possible to determine the potential food value of sediment on a scale equivalent to that perceived by infaunal deposit-feeders.
\end{abstract}

\section{INTRODUCTION}

Trophic resource studies of marine deposit-feeders usually involve some examination of the sediment which is presumed to be the animal's food source. Usually a 'scoopful' of sediment is taken from the sample bearing the deposit-feeding organisms, and this sediment is characterized in terms of the amount of organic $C$ and $N$, measures of central tendency of particle size for the mineral fraction, and a variety of other bulk measures. It is unlikely that any of these measures can be adequately related to those aspects of the sediment actually being perceived by the depositfeeder's sensory structures. It is also improbable that these measures can be meaningfully related to the organism's metabolic requirements. If the processes governing the successful maintenance of depositfeeder populations are to be understood, bulk measures of sediment properties must be augmented by methods that will give information relatable to the scale of the organisms under study. This recommendation was made by Johnson (1974), but it has scarcely been heeded. He urged benthic ecologists to devise measures of the food resource and its partitioning that were relevant to the requirements and activities of benthic animals. In order to do this, biological, chemi$\mathrm{cal}$, and geological techniques must be developed that investigate the environment at the appropriate spatial scale.

Many techniques for the fine-scale study of sediment have been developed by persons interested in the formation and ecology of soils and in the fabric of marine muds. Thin sections have been used to study the details of soil fabric structural features of soil porosity, microenvironments of soil, interactions between plant structures and soil particles, as well as features of soil mineral components (FitzPatrick 1984). Torresan \& Schwab (1987) note that with the exception of a few studies, little is known of the fabric of recently deposited marine sediment. While thin sections have been used to investigate microfabric structures in marine sediment (Kuehl et al. 1988), the techniques used (freezing and drying) and the scale of the micrographs (usually on the order of 2 or more $\mathrm{cm}$ ) are not usable for the study of sediment from an ecological point of view. The techniques used result in contraction and shrinkage of the organic matrix, producing artifacts, and the scale of the micrographs does not show the detail required to understand the relationship between the organic structures and the mineral grains.

Sediment micromorphology is concerned with the particles, biogenic structures, and other constituents of sediment and the way in which they are organised or inter-connected. Before turning to the individual com- 
ponents, we need to establish an understanding of the terms fabric, structure, and matrix, as these are commonly used to denote the manner and degree of physical relationships between the components.

FitzPatrick (1984) reviewed these terms and offered some solutions to the ambiguity that their use often caused. He recommended, when soil micromorphology is being described, that the following terms be used:

Coarse material: individual mineral grains, small rock fragments or fragments of organic matter that are easily resolved with the petrological microscope.

Fabric: the arrangement, size, shape, and frequency of the individual soil constituents.

Fine material: the organic and/or mineral material less than $2 \mu \mathrm{m}$ that is not easily resolved with the petrological microscope.

Matrix: material forming a more or less continuous phase and enclosing coarse material, concretions, etc. Generally refers to material less than $2 \mu \mathrm{m}$ (fine material) but may be much larger. Fine material/matrices are often uniform but may be speckled.

Structure: the spatial distribution and total organization of the soil system as expressed by the degree and type of aggregation and the nature and distribution of pores and pore space.' (p. 134-135)

These terms are in wide use in the study of marine sediment and will be used here. Kuehl et al. (1988) noted other terms describing microfabric structures coined by soil scientists that were of use in the study of marine sediment.

In this paper, micro-scale features of marine sediment will be examined, and specific thin-sectioning techniques for preserving and delimiting these features will be outlined. In addition, the importance of some of these features will be reviewed and their significance will be discussed in terms of developing an understanding of the relationship between marine depositfeeders, the sediments which they inhabit, and the means by which they ingest the components of these sediments.

\section{METHODS}

In order to examine the small-scale features of marine sediment it is necessary to ensure that these features are maintained in their original form during the preparation of thin sections. The techniques described here have, for the most part, been borrowed and modified from those already in the literature on terrestrial soils and from well-known histological procedures; some others were presented in Bouma (1969) - an excellent general text which deals with many aspects of the study of sedimentary features.

Sediment samples were taken using small metal forms encompassing a surface of $1 \times 3 \mathrm{~cm}$, to a depth of about $3 \mathrm{~cm}$. The protocol follows the same 3 basic steps as standard histological technique: preservation, dehydration, and embedding. All the times given below were adjusted according to the estimated degree of permeability of the sediment block.

Preservation: The sample with its metal form was carefully immersed in $10 \%$ formalin (prepared with seawater) for 3 to $5 \mathrm{~d}$ to ensure complete penetration. Two formalin changes followed at $3 \mathrm{~d}$ intervals, one made with $50 \%$ seawater and the next with freshwater. The last wash was necessary to remove salt ions which may form crystals in the following steps.

Dehydration. Acetone was used as the dehydration agent. Each step consisted of replacing part of the solution with pure acetone to achieve a dehydration series of $5 \%, 10 \%, 25 \%, 50 \%, 75 \%, 85 \%, 90 \%, 95 \%$, $100 \%, 100 \%$ acetone. Each step lasted about $8 \mathrm{~h}$. It was found that the sediment block should not be moved through the solution-air interface as the consequent repeated draining of the sample resulted in the loss of some material.

Embedding. After the sample was completely dehydrated, it was moved to an embedding container to which PolyBed 812 resin mix was added until the sample was totally immersed. To aid the penetration of PolyBed into the block, particularly with very fine sediments, the sample was placed in a vacuum dessicator at $10 \mathrm{psi}\left(\approx 7 \times 10^{4} \mathrm{~Pa}\right.$ ). After curing overnight at $70^{\circ} \mathrm{C}$, the sample was removed from its metal form for sectioning. Several sections were cut from each block, glued to glass slides and polished to a thickness of 30 um using standard petrographic techniques.

\section{RESULTS}

As an introduction to the variety of features that may be seen by using micro-morphological methods, various kinds of sediment structure, matrix, and major biogenic components are presented below. Where appropriate, features of special importance to marine deposit-feeders will be discussed. All examples are from a section taken at 3 to $4 \mathrm{~cm}$ below the surface of the mudflat at Lowes Cove, Maine, USA. This layer has been shown by Rice (1986) to be near the feeding zone of the polychaete Leitoscoloplos robustus.

\section{Structure}

Sediment structure is best described as the degree and type of aggregation of the particles in relation to the nature and distribution of pores and pore space. In most soils the individual particles are not distributed randomly, but occur as members of aggregates. The 
degree of aggregation is often a function of the heterogeneity of particle size. Many types of aggregates have been described in terrestrial soils (see FitzPatrick 1984 for descriptions); however, aggregates in marine sediments have never been documented in thin section, although their occurrence has been inferred from sediments that have been disrupted. Consequently, it is difficult to know what types and sizes of aggregates (if any) might be found. It should be stressed that the term aggregate as used here is quite different from its typical usage in marine benthic studies (e.g. as 'organic-mineral aggregate', first proposed by Johnson 1974).

Johnson $(1974,1977)$ was the first to note the occurrence of what he termed 'organic-mineral aggregates' in marine sediments. He used this term to describe mineral grains that were embedded in an amorphous (presumably organic) matrix. Johnson took a small amount of sediment and dispersed it on a slide. As a result, none of the aggregates he saw were necessarily in situ structures, but could have been artifacts produced by fragmenting the sediment matrix while dispersing the grains. He distinguished these structures from encrusted mineral grains, which were composed primarily of mineral material bearing thin organic coats. Using similar techniques, other authors have since recorded the occurrence of organic-mineral aggregates in a variety of marine sediments (e.g. Whitlatch 1974, 1981, Hughes 1979). As noted in the next section, however, these aggregates are almost certainly artifacts of the sediment dispersion process and do not exist in situ.

\section{Matrix}

The most striking feature of thin sections of marine muddy sediment is the ubiquitous presence of matrix, the fine material that is not resolvable with the light microscope. The matrix forms bridges between grains in marine sands (Frankel \& Mead 1973), but completely encompasses all grains in muddy sediments (Fig. 1). Grains of all sizes have varying proximity to one another, but they are usually separated by some amount of matrix (Fig. 2). Since the illustrated sections were cut at $30 \mu \mathrm{m}$ thickness, there is an apparent differentiation of features. Those larger than $30 \mu \mathrm{m}$ will stand out from the matrix, whereas those smaller than $30 \mu \mathrm{m}$ will be completely embedded in the matrix and, therefore, will not be as noticeable. At $100 \times$ magnification, the larger grains stand out quite clearly from the matrix (Fig.3), whereas even at $400 \times$ the smaller grains cannot easily be discerned and may be missed entirely (Fig. 4). Use of crossed polarizers aids in the differentiation of the smaller grains, but is not effective for grains much smaller than $10 \mu \mathrm{m}$ (Fig. 5).
A close examination of the matrix shows that it is not of uniform density. If one examines grain boundaries carefully, certain sites are seen to have higher density of matrix than others (Fig. 6a). Occasionally, autofluorescence techniques will show these higher density areas to be occupied by living diatoms (Fig. 6b), but usually it is not possible to determine the nature of the material at these sites. These higher density sites are probably areas of biological activity, resulting in localized patches of matrix where the adhesive forces are strongest between the grain surface and the organic matter. When the sediment is disrupted the organic matter then stays with the grain, resulting in an 'encrusted' grain.

The matrix has been found to contain polysaccharides in terrestrial soils (Foster 1981) and large amounts of pectic carbohydrates and some proteins in marine sands (Frankel \& Mead 1973). Many other organic compounds have been isolated from soils and marine sediments, including the ubiquitous humic substances, proteins, and lipids (Mayer 1985, Mayer et al. 1986); however, the degree to which these compounds occur in the matrix versus in bacteria, protists, faunal and floral elements, or in solution, is unknown. It does seem clear, however, that microorganisms (including both bacteria and diatoms) are among the major agents producing the organic compounds in the matrix (Webb 1969, Frankel \& Mead 1973, DeFlaun \& Mayer 1983). Other sources of this material are the mucus products secreted by feeding meiofauna (e.g. mucus nets produced by nematodes: Riemann \& Schrage 1978), mucus trails of turbellarians (Klauser 1986) and macrofauna (Lawry 1967) as well as the mucus produced by many organisms for such functions as locomotion (Trueman 1975).

The part of the matrix investigated using histochemical techniques is that which adheres to the mineral grains when the grains are dispersed on a microscope slide. Whitlatch \& Johnson (1974) and Whitlatch (1974) were the first to apply standard histological staining techniques to such dispersed marine sediments. They used the periodic acid-Schiff (PAS) reaction for carbohydrates, mercuric bromphenol blue (MBB) for proteins, and Sudan Black B (SBB) for lipids. The stains were applied to very small amounts of sediment which were then dispersed on a microscope slide for evaluation. Whitlatch (1974) noted that only $13.9 \%$ of the material stained positively for PAS, while less than $0.4 \%$ showed MBB reactions and less than $0.1 \%$ SBB reactions. He concluded that less than half of the possible ingestible items were, in fact, organic in nature.

Gelder (1984) used histochemical techniques and polarizing filters (Gelder 1983) to examine organic coatings on the surface of grains from the Lowes Cove tidal flat. Acid glycoproteins and compounds contain- 

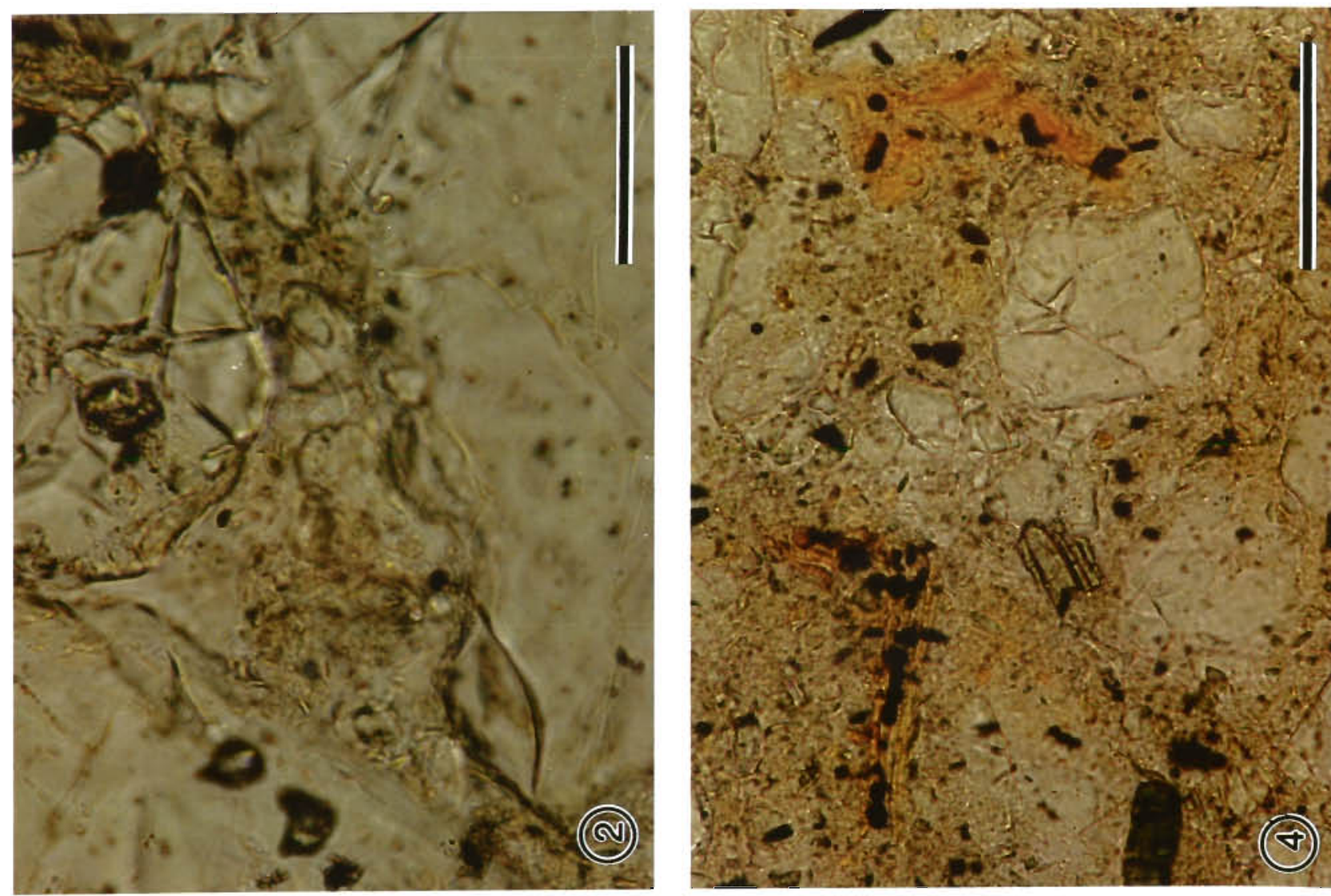

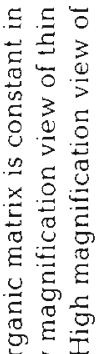

$53=0$

लं

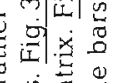

$\Xi \tilde{\sigma}$

जै:

兄豆要

万人

造

政

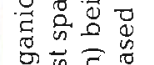

○。

क ह

实焉岳

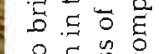

व
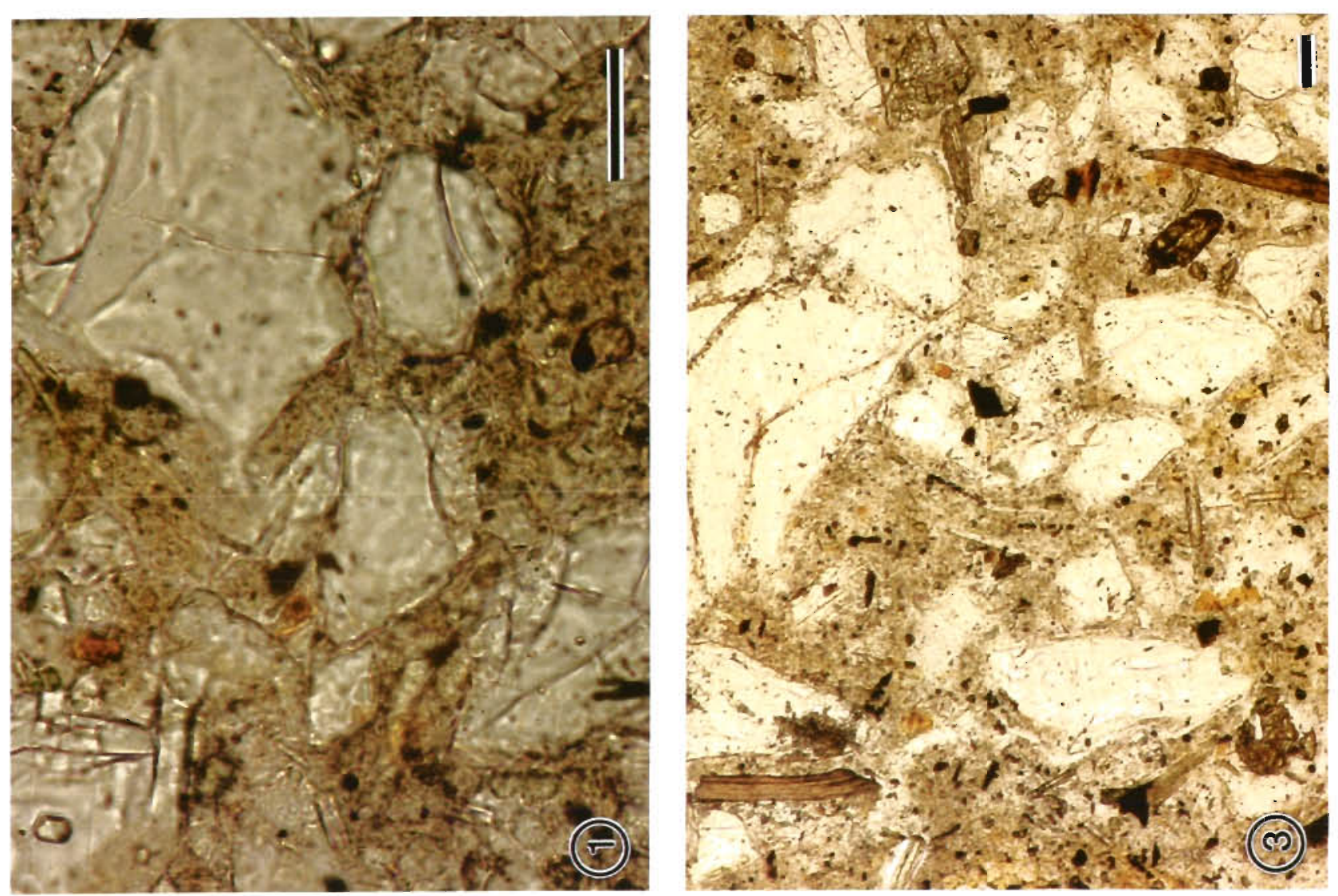

로요

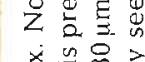
뜰 을 要造要 $\div \sum \stackrel{5}{0}$ \& 5 ه

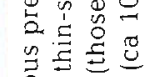

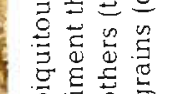

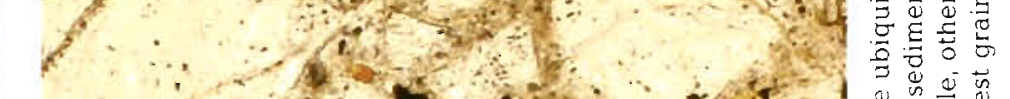

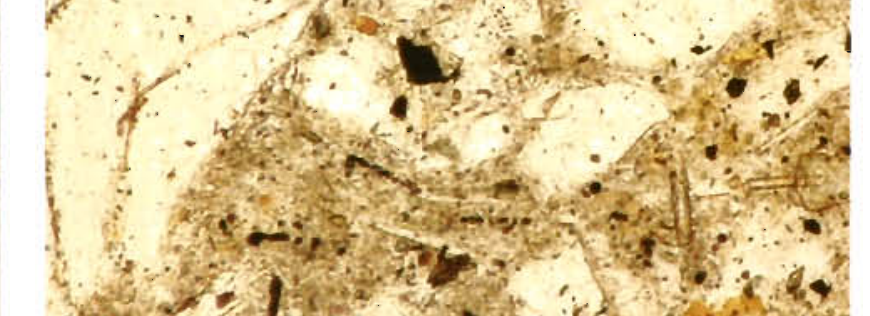

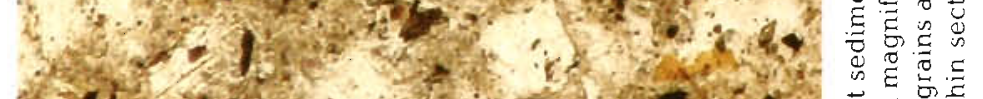

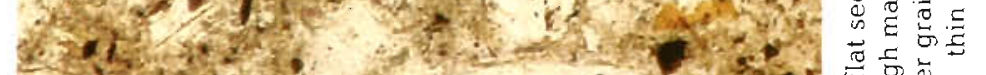

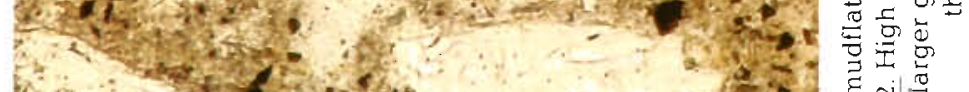

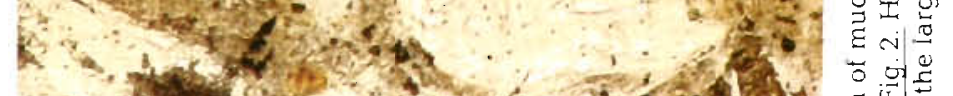

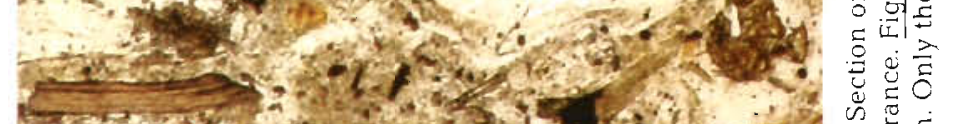

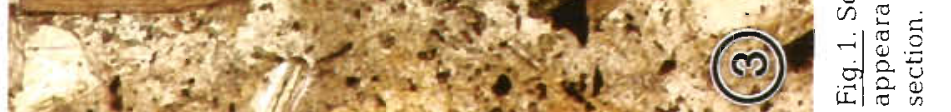


Fig. 5. Thin section viewed through partially crossed polarizers. All but the smallest grains are clearly differentiated from the surrounding matrix. Scale bar $=50 \mu \mathrm{m}$

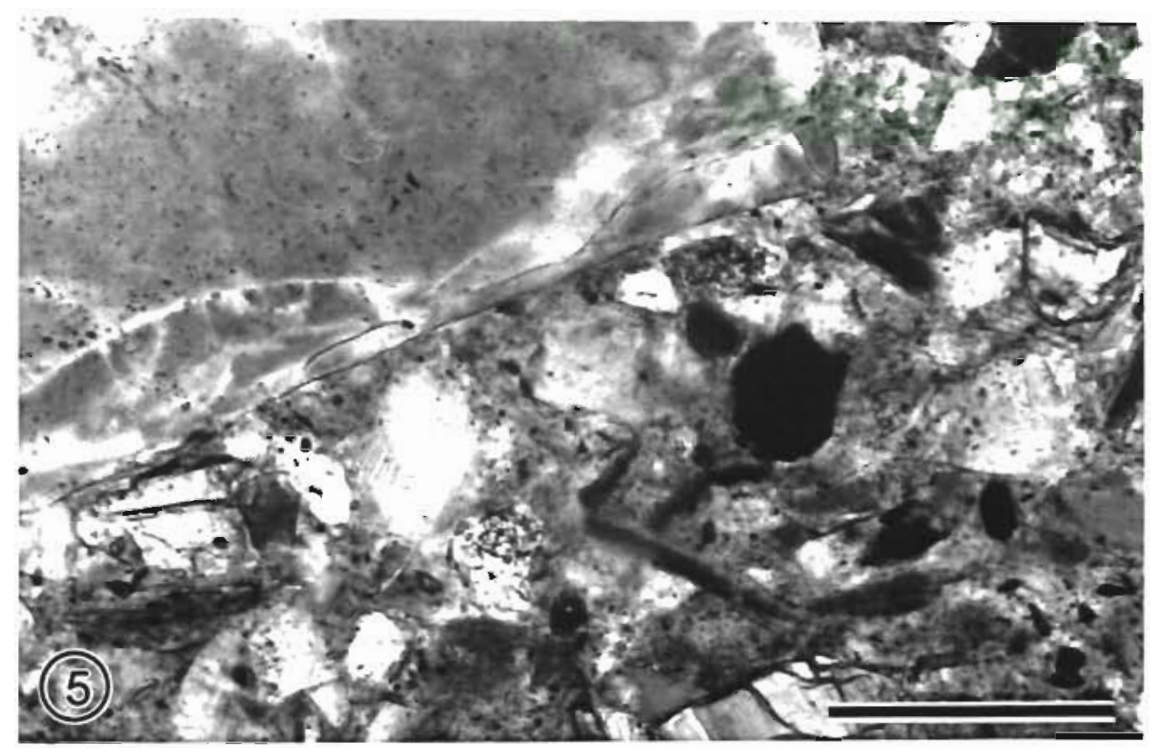

ing the 1,2 glycol group were stained with Alcian blue $(\mathrm{pH} 2.5$ or 1.0$)$ and PAS reaction, respectively (ABPAS). MBB was used for basic proteins while all proteins were stained with Coomassie BB R250 (CR250) following ethanol-acetic acid fixation. Almost half of the material he examined consisted of mineral grains with various types of organic coats. The remaining material was almost entirely organic matter that stained PAS-positive and consisted of amorphous flocculent material, microorganisms, and organic fragments.

\section{Organic particles}

Many different kinds of organic particles that might be used as food items by deposit-feeders can be found in marine sediments. These usually include living diatom and other algal cells, meiofaunal taxa such as Foraminifera, ostracods, copepods, and acoel turbellarians, chitinous molts of various crustaceans, shell fragments of molluscs, fragments of terrestrial plants, and setae and jaws of polychaetes (Johnson 1974). The number and type of particles likely to be found will vary with water depth and distance from shore (Hargrave 1975) as well as depth within the sediment column (Johnson 1977). For example, in most nearshore regions where marshes are common, fragments of Spartina marsh grass are abundant. In Maine, terrestrial plant fragments seen in the sediment also include those derived from oak leaves and pine needles (Fig. 7), but many of the organic particles may be derived from the large biomass of attached macroalgae living along the shore (Webster et al. 1974, Hughes 1979, Josselyn \& Mathieson 1980).
A large number of autofluorescing chloroplasts were observed in the mudflat thin sections. Most were associated with large fragments of terrestrially-derived organic material (Fig.8), indicating that these plant fragments either were buried quite recently or had resisted microbial attack for some unknown amount of time. Other autofluorescing chloroplasts were seen in diatom cells. Some of these were obviously chain-forming planktonic forms that had become buried (Fig. 9a, b), whereas others were clearly associated with large sediment grains (Fig.6b). Several of the planktonic forms were enclosed in fecal pellets, suggesting a mode of burial that has not been fully investigated. Two grains that had chloroplasts associated with them were relatively large. In neither case could it be determined from transmitted light microscopy that high numbers of diatoms were present although the matrix at those sites was of slightly darker color.

\section{Pores and pore spaces}

Owing to the through-drainage of water, pore space plays a much more important structural role in terrestrial soils than it does in marine sediments, with the possible exception of sandy substrata containing very low amounts of silt and clay. Information about in situ pore space volume generally has been inferred from measures of sediment water content. Harrison \& Wass (1965), using a least squares multiple regression analysis, determined that water content was the most useful mass property of marine sediments for predicting abundances of 3 infaunal species. They noted that water content reflected the interrelationships of mean grain size, sorting, grain packing, and mineralogy, 

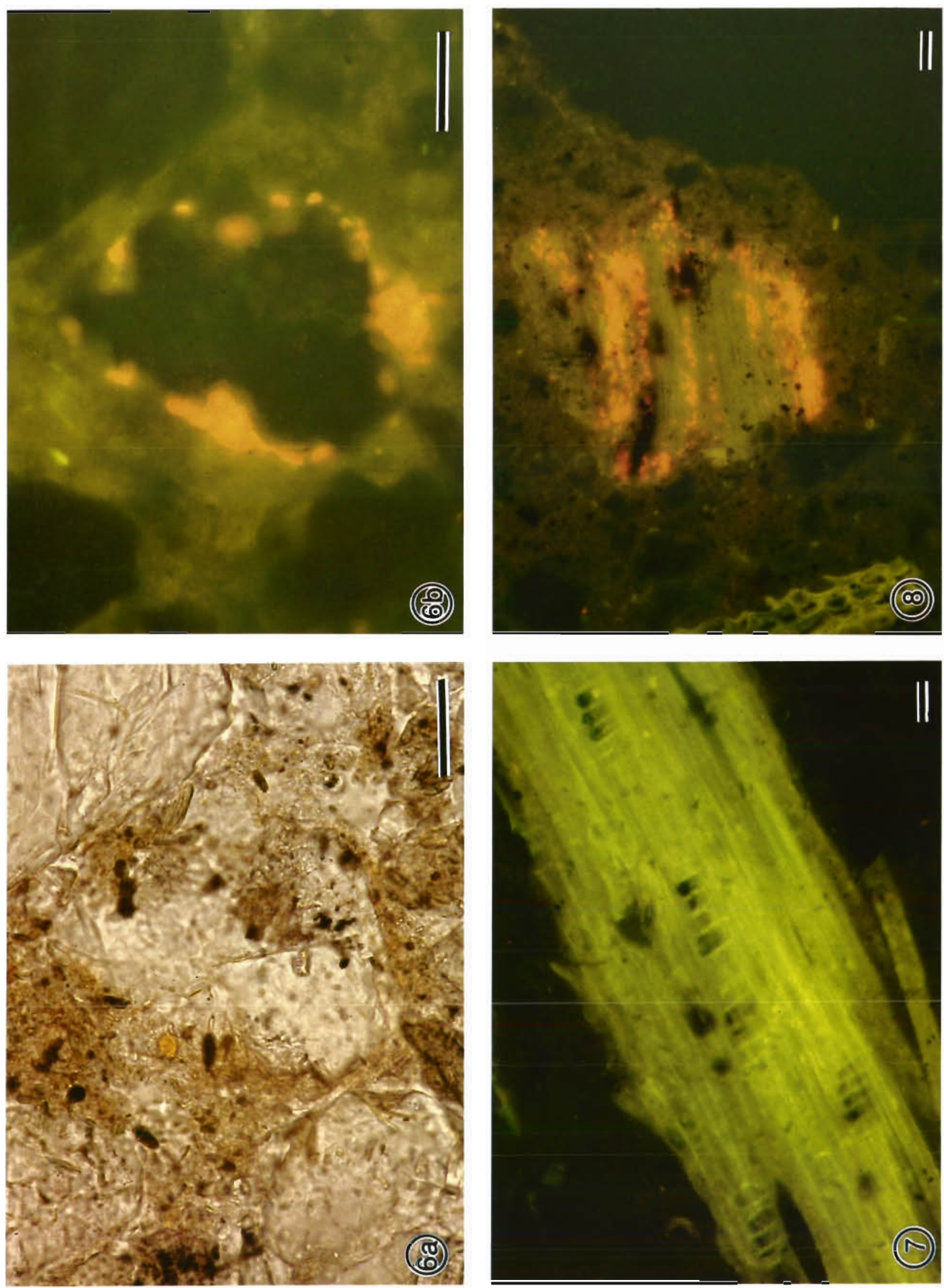

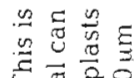

둥

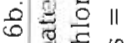

可

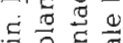

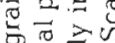

$Ð \frac{1}{0} \stackrel{0}{ }$

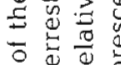

응

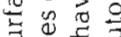

क

可要

영

도음용

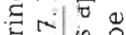

In:

단)

$\circ$ o

政

\& $0=3$

긍

을

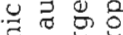

d. 응

क्ष

옹 है.

的的

(ே)

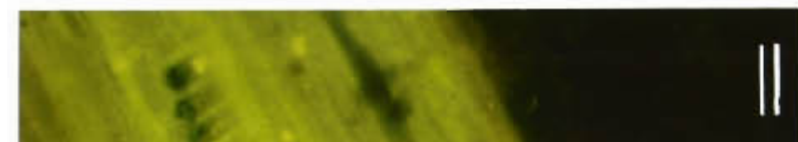

5

응

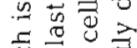

둥

3 글

خo

की

क ज

$\subseteq$ 총

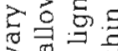

Q $匚$ 过

둥

i

ब है

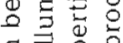

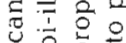

u $\overrightarrow{2}$ 品

\& 0

至

웜

83

过

훙

品

要.

品

$\times$

壳氠

$E$ E

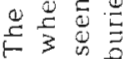

j है

0.0 

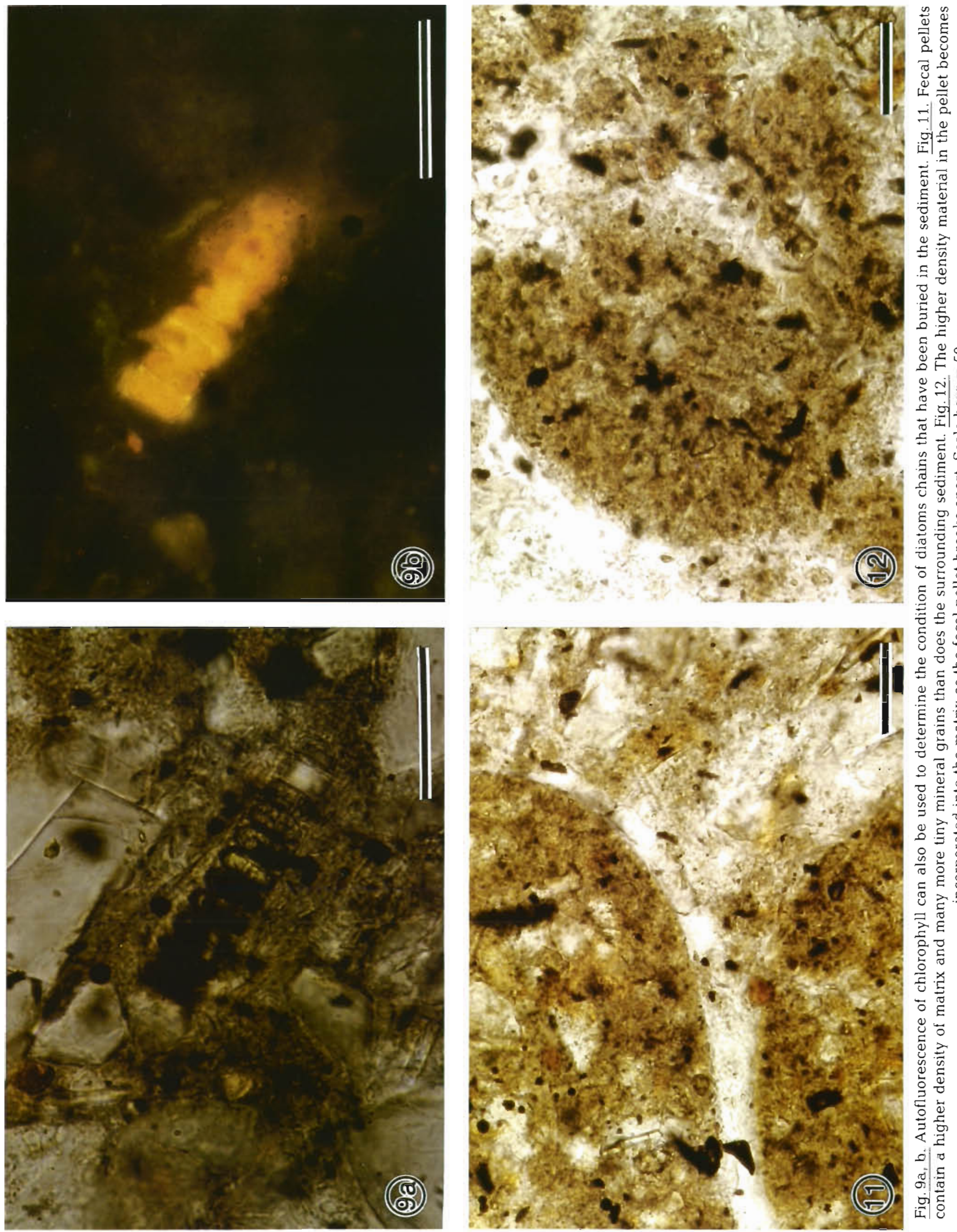

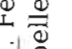
: 五 可 $\frac{0}{0}$ 要 $\stackrel{Z}{\vec{n}}$ 政 \% 등 ق 웡 . F in

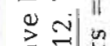
胥

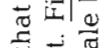
$\vec{E}$ 寻 응 no 임 응 동 홍 胥 告

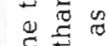
至 害苛苟 $\tau$

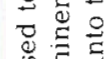
文 $\doteq \Xi \frac{\pi}{\pi}$ $\stackrel{\circ}{\circ}$ $\pi$ 范 gु 글 흥 \% 总 ठ $\stackrel{0}{0}$ ปे

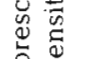
웡 후 을 $\pi$
$-\pi$ 5. 5 


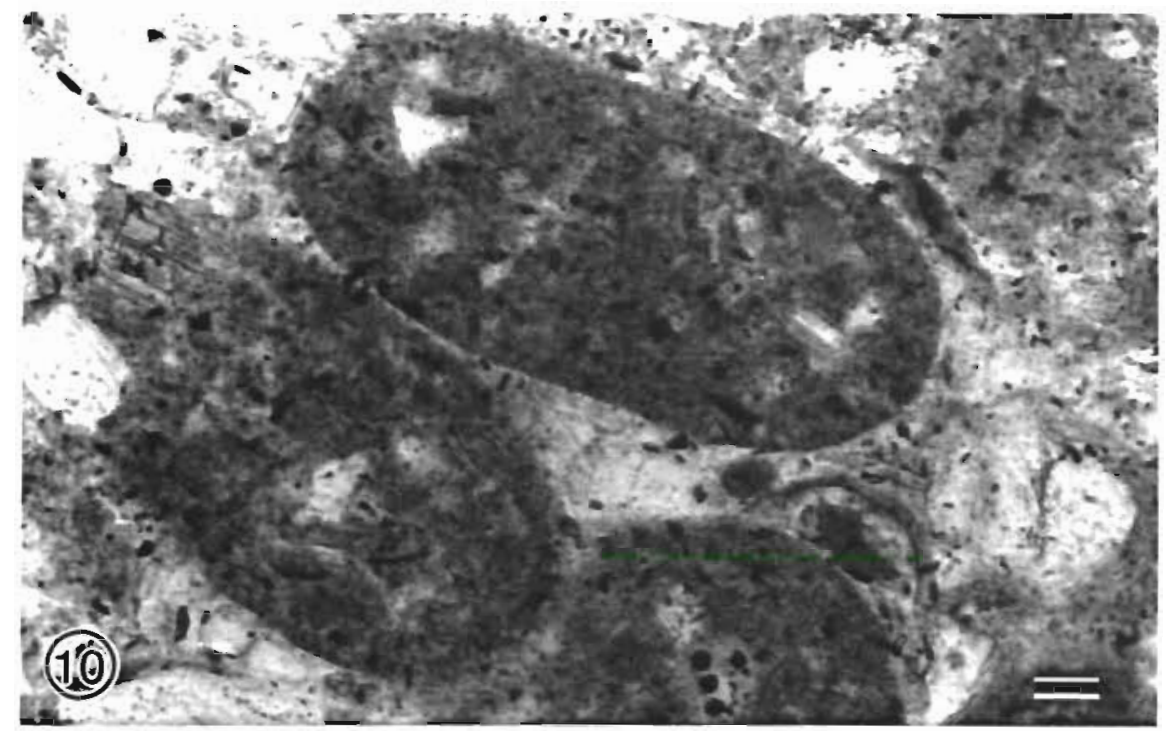

Fig. 10. Intact fecal pellets observed at a depth of 3 to $4 \mathrm{~cm}$ in the section which would be expected if water content is, in fact, related to pore space. Rhoads (1974) suggested that deposit-feeders, by their feeding activities, may exert a strong influence on porosity, water content, cohesion, and compaction of the sediment as a result of their binding small sediment grains into fecal pellets.

Webb (1969) suggested that the pore space of marine sands could be divided into 2 types, based on the degree of water flow. Capillary space is defined as that part of the pore space where water would preferentially flow, with water flow being highly reduced in the remainder, termed cavity space. Through his experiments, Webb determined that organic epipsammic films tended to reduce the capillary space and increase the cavity space, but the overall porosity was increased. This would be a result of the apparent increased size of the grain as the epipsammic film was produced. The matrix in marine muds can perhaps be thought of as an extensive development of this epipsammic film. It is so extensive, however, that it is currently not possible to determine what proportion of the space between grains is occupied by organic material or water.

Water content also has been noted to increase as other factors, such as pelletization (Rhoads \& Boyer 1982), increased. However, while there has been considerable indirect measurement of the extent of pore space in marine sediments, there is little direct information about these voids, their sizes, or their distributions in the matrix surrounding the mineral grains. From water content data it is known that considerable pore space is present, and from data on flow of water through the sediment, one can infer that it is cavity space rather than capillary space. At this time, it is not possible to differentiate these types of pore spaces in thin sections of marine muds.

\section{Pellets}

Many marine invertebrates defecate material in the form of pellets. These may take a wide range of shapes and sizes (Kraeuter \& Haven 1970). Regions of the sea bottom with high densities of deposit-feeders often have a significant proportion of the mineral grains bound into fecal pellets (Rhoads \& Young 1971). Intact fecal pellets were observed (Fig. 10) in some areas of the section. It is not known whether these were produced at this depth in the sediment or whether they were produced at the surface and survived burial intact (although the latter process seems unlikely). Pellets contain a higher density matrix and many smaller grains per unit area than is commonly seen throughout most of the thin section (Fig. 11). As the pellet breaks apart, this finer grained material is spread into the surrounding sediment (Fig. 12).

\section{DISCUSSION}

Food resources for deposit-feeders have characteristically been studied by taking small amounts of sediment, smearing it on a microscope slide, and then. staining the smear to determine the presence of carbohydrates, proteins, or lipids (Whitlatch 1974, Gelder 1983) or by taking larger amounts of sediment and performing bulk chemical analyses for protein, etc. (Mayer et al. 1986).

The first of these techniques seems to produce major artifacts due to the complete disruption of the sedimentary structure. For example, what has been termed 'organic-mineral aggregates' by benthic ecologists do not exist in situ. Rather, they are probably fragments of 
the matrix containing very small embedded mineral particles. That the matrix surrounds all particles, of whatever size, can be seen in the thin sections. There must be some uneven distribution of the adhesivecohesive forces in the matrix such that 'aggregates' are formed as the sediment is disrupted. A second consequence of this disruption is the production of 'clean' vs 'encrusted' grains. There is some evidence from the thin sections that encrusted grains exist in situ, that is, microbes attach to the surface of a grain and create a layer of material that has stronger adhesive bonds to the grain than to the surrounding matrix. Clean grains are probably those without such microbial attachment and therefore, when the sediment is disrupted, they become separated from the matrix.

Chemical techniques can produce very detailed accounts of the organic components in marine sediments (Klok et al. 1983, 1984), but because of the large amounts of material needed and the time and expense to run these analyses, little information can be gained regarding the small-scale spatial distribution of the various compounds. Duchaufour et al. (1984) attempted to overcome some of these problems by using mechanical disaggregation and size fractionation techniques. The various fractions were examined microscopically before being analysed for organic compounds. In this way it could be determined whether 'organic-mineral aggregates', large plant fragments, etc, were being chemically characterized. While it does not seem possible to do detailed chemical analyses on the matrix of thin sections, it may be possible to approximate those results by using histochemical techniques (Gelder 1983). Using autofluorescence or crossed polarizers, it is possible to determine what proportion of the volume of thin section being examined is occupied by large $(>40 \mu \mathrm{m})$ mineral grains and plant fragments. The remaining volume then is resin (filling the space occupied by water in situj, small mineral grains, and the organic material making up the bulk of the matrix. The application of histochemical techniques to the thin-sectioned material should allow the direct characterization of the major organic constituents and their spatial arrangements.

The thin sections already examined show a patchiness of large mineral grains that exists on a scale of half a centimeter or so. Where the grains are densely packed, there is little matrix. On the other hand, where fecal pellets, for example, are breaking up in the sediment column, the matrix is very dense. The increased density is probably a direct result of the large number of small grains contained in these pellets. An increase in organic carbon and nitrogen content should be associated with this fine material (Cammen 1982, DeFlaun \& Mayer 1983). Thus, a subsurface-feeding worm that could 'taste' these differences in organic content may then actively search for such pockets in the sediment.

Of course, in order to quantify the food resources for deposit-feeders, we must first know what it is exactly that deposit-feeders consider as a food resource. To date, such studies have concentrated on the various degrees of relationship between the sediment grains and attached organic matter. Whether as part of 'organic-mineral aggregates' or 'encrusted grains', the assumption has always been that the mineral grain is an integral part of the food resource, even though it is understood that the animal can get no nutritional value from the grain. The myriad number of studies reporting the size range of mineral grains ingested bears ample testimony to this fact.

In these thin sections we have seen that the organic matter in marine sediments exists all around the mineral grains, but only in a few instances does it have any direct attachment to the grains. Consequently, it is unlikely that subsurface deposit-feeders, at least, are using the mineral grains in any way, not even as cues for other factors. Rather, it is probable that the mineral grains found in the organism's gut are those that could pass through the mouth opening, and the animal was in fact either feeding on everything directly in front of it, or was somehow sensing the quality of the organic matter in the matrix.

Attempts to quantify the patchiness of food resource for deposit-feeders must then concentrate on 2 factors: the distribution and concentration of organic matter; and the regions of the sediment where there are relatively large numbers of grains that are too large (for example, greater than $200 \mu \mathrm{m}$ in diameter) to fit into the animal's mouth. Both kinds of patches have been seen to exist in the thin sections examined so far, usually on the scale of a millimeter or so.

Acknowledgements. I thank S. Staples for her help with developing the thin-section technique, J. Watling for taking such great care with the printing of the color photographs and B. McKenzie for producing the black and white prints. This paper benefited from the careful reviews of $R$. Whitlatch and L. Mayer, neither of whom agrees with all of my views. Many of the ideas contained herein were developed through discussions with the members of the Maine Benthic Oceanography Group, and those participating in the DEPOFEX Workshop at the Darling Marine Center in 1986, to whom I would like to express my appreciation. Funds for this research were provided by NSF grant ISP-8011448 and the University of Maine Center for Marine Studies. This is Darling Marine Center contribution No. 200

\section{LITERATURE CITED}

Bouma, A. H. (1969). Methods for the study of sedimentary structures. John Wiley \& Sons, New York

Cammen, L. (1982). Effect of particle size on organic content 
and microbial abundance within four marine sediments. Mar. Ecol. Prog. Ser 9: 273-280

DeFlaun, M. F., Mayer, L. M. (1983). Relationships between bacteria and grain surfaces in intertidal sediments. Limnol Oceanogr. 28: 873-881

Duchaufour, H., Monrozier, L. J., Pelet, R. (1984). Optical and geochemical studies of granulometric fractions from recent marine sediments. Org. Geochem. 6: 305-315

FitzPatrick, E. A. (1984). Micromorphology of soils. Chapman $\&$ Hall, London

Foster, R. C. (1981). Polysaccharides in soil fabrics. Science 214: $665-667$

Frankel L., Mead, D. J. (1973). Mucilagenous matrix of some estuarine sands in Connecticut. J. sedim. Pet. 43 1090-1095

Gelder, S. R. (1983). Enhancement of histochemically demonstrated organic materials on sand-silt grains using polarized light. Tech. Inf. Bull., Leitz, USA 1: 11-12

Gelder, S. R. (1984). Diet and histophysiology of the alimentary canal of Lumbricillus lineatus (Oligochaeta, Enchytraeidae). Hydrobiologia 115: 71-81

Hargrave, B. T (1975). The importance of total and mixedidyer depth in the supply of organic material to bottom communities. Symp. Biol. Hung. 15: 157-165

Harrison, W., Wass, M. L. (1965). Frequencies of infaunal invertebrates related to water content of Chesapeake Bay sediments. Southeastern Geol. 6: 177-187

Hughes, T. G. (1979). Studies on the sediment of St. Margaret's Bay, Nova Scotia. J. Fish. Res, Bd Can. 36: 529-536

Johnson, R. G. (1974). Particulate matter at the sedimentwater interface in coastal environments. J. mar. Res. 32: 313-330

Johnson, R. G. (1977). Vertical variation in particulate matter in the upper twenty centimeters of marine sediments. J. mar. Res. 35: 273-282

Josselyn, M. N., Mathieson, A. C. (1980). Seasonal influx and decomposition of autochthonous macrophyte litter in a north temperate estuary. Hydrobiologia 71: 197-208

Klauser, M. D. (1986). Mucous secretions of the acoel turbellarian Convoluta sp. Orsted: an ecological and functional approach. J. exp. mar. Biol. Ecol. 97: 123-133

Klok, J., van der Knapp, J. M. M., DeLeeuw, J. W., Cox H. C., Schenck, P. A. (1983). Qualitative and quantitative characterization of the total organic matter in a recent marine sediment. In: Bjoroy, $M$. et al. (eds.), Advances in organic geochemistry. John Wiley, New York, p. 813-818

Klok, J., Baas, M., Cox, H. C., DeLeeuw, J. W., Rijpstra, W. I. C., Schenck, P. A. (1984). Qualitative and quantitative characterization of the total organic matter in a recent marine sediment (Part II). Org. Geochem. 6: 265-278

Kraueter, J., Haven, D. S. (1970). Fecal pellets of common invertebrates of lower York River and lower Chesapeake Bay, Virginia. Chesapeake Sci. 11: 159-173

Kuehl, S. A., Nittrouer, C. A., DeMaster, D. J. (1988). Mic- rofabric study of fine-grained sediments: observations from the Amazon subaqueous delta. J sedim. Petrol. 58: $12-23$

Lawry, J. V (1967). Structure and function of the parapodial cirri of the polynoid polychaete Harmothoe. Z. Zellforsch. mikrosk. Anat. 82: 345-361

Mayer, L. M. (1985). Geochemistry of humic substances in estuarine environments. In: Aiken, G. R., McKnight, D. M., Wershaw, R. L., MacCarthy, P. (eds.) Humic substances in soil, sediment, and water: geochemistry, isolation, and characterization. John Wiley \& Sons, New York, p. 211-232

Mayer, L. M., Schick, L. L., Setchell, F. W. (1986). Measurement of protein in nearshore marine sediments. Mar. Ecol. Prog. Ser. 30: 159-165

Rhoads, D. C. (1974). Organism-sediment relations on the muddy sea floor. Oceanogr. mar. biol. A. Rev. 12: 263-300

Rhoads, D. C., Boyer, L. F. (1982). The effects of marine benthos on physical properties of sediments, a successional perspective. In: McCall, P. L., Tevesz, M. J.S. (eds.) Animal-sediment relations. Plenum Publ. Corp., New York, p. 3-53

Rhoads, D. C., Young, D. K. (1971). Animal-sediment relations in Cape Cod Bay, Massachusetts. II. Reworking by Molpadia oolitica (Holothuroidea). Mar. Biol. 11: 255-261

Rice, D. L. (1986). Early diagenesis in bioadvective sediments: relationships between the diagenesis of beryllium-7, sediment reworking rates, and the abundance of conveyor-belt deposit-feeders. J. mar. Res. 44: 149-184

Riemann, F., Schrage, M. (1978). The mucus-trap hypothesis on feeding of aquatic nematodes and implications for biodegradation and sediment texture. Oecologia (Berl.) 34 : $75-88$

Torresan, M. E., Schwab, W C. (1987). Fabric and its relation to sedimentologic and physical properties of near-surface sediment, Shelikof Strait and Alsek prodelta, Alaska. J. sedim. Petrol. 57: 408-418

Trueman, E. R. (1975). The locomotion of soft-bodied animals Edward Arnold, London

Webb, J. E. (1969). Biologically significant properties of submerged marine sands. Proc. R. Soc. Lond. B. 174: 355-402

Webster, T J. M., Paranjape, M. A., Mann, K. H. (1975) Sedimentation of organic matter in St. Margaret's Bay, Nova Scotia. J. Fish. Res. Bd Can. 32: 1399-1407

Whitlatch, R. B. (1974). Food-resource partitioning in the deposit feeding polychaete Pectinaria gouldii. Biol. Bull. mar, biol. Lab., Woods Hole 147: 227-235

Whitlatch, R. B. (1981). Animal-sediment relationships in intertidal marine benthic habitats: some determinants of deposit-feeding species diversity. J. exp. mar. Biol. Ecol 53: $31-45$

Whitlatch, R. B., Johnson, R. G. (1974). Methods for staining organic matter in marine sediments. J. sedim. Pet. 44 $1310-1312$ 